\title{
My first Mathematical Gazette
}

\section{MICHAEL CORNELIUS}

'You ought to join the Mathematical Association.'

So said my Head of Department soon after I started teaching and I duly sent off the application form he gave me. In due course a package arrived from the Association Headquarters in Gordon Square, London containing a grey journal with an equally grey Teaching Report (Analysis I think). Thus my first contact with the Association was through the Mathematical Gazette Number 355, dated February 1962. My copy has a well-thumbed appearance suggesting that, as a new teacher, I read it in great detail.

It is fascinating to browse through old Gazettes. This one in particular revealed:

- a cover price of $5 \mathrm{~s} 6 \mathrm{~d}$

- an advertisement for a Road Research Laboratory Scientific Officer at a starting salary of $£ 738$ ( $£ 144$ s 0 d per week!)

- a review of a new edition of Northrop's Riddles in Mathematics costing 3s $6 \mathrm{~d}$

- articles including: 'On Functions which form a Group'

'Should there be a Choice of Questions in an Examination Paper?'

'Early Nineteenth Century Mathematics'

There were also classroom notes including one entitled 'An interesting series' which begins: 'Even in the Primary School, something of exceptional interest crops up from time to time.' and then goes on to look at an investigation into counting the number of triangles in a pattern. The note would not be out of place in any of the Association journals today - so much for the notion that the MA used to be concerned only with higher levels of mathematics or that investigations are something new!

Professor Goodstein was the editor of the Gazette in 1962, soon to be succeeded by E. A. Maxwell (not many years earlier I had been interviewed by Dr Maxwell for a place at Queens' College, only to be rejected!). J. T. Combridge was President in 1961-62 - I went to the Association's Annual Meeting in London in April 1962, it was there that Combridge gave a presidential address with the title 'Mathematics - slave, servant or sovereign?' and Geoffrey Matthews gave his famous 'Matrices for the million' presentation.

This leads to Gazette Number 359 dated February 1963 which appears to be one of the most used of my Gazettes. It contained Matthews' talk and articles on 'Modern mathematics in fifth forms' and 'The School Mathematics Project'. This was the beginning of teaching matrices and sets to almost everybody; 'Modern' mathematics was starting. Where do we find 
sets and matrices now? Certainly not at levels 3-4 in the National Curriculum. It was exciting at the time, produced many bemused teachers and parents and created a 'modern' versus 'traditional' debate but, looking back, was it a wrong turning?

Out of my pile of early Gazettes falls Number 358, dated December 1962. I notice that it cost $21 \mathrm{~s}$ per annum to be a member at that time. But my eye is caught by a longish section of Branch Reports: Nottingham, North Staffordshire, Exeter, Yorkshire, Cambridge, Cardiff, Leicester, Southampton, Wolverhampton, New South Wales. Typically they contain statements of the kind, 'The average attendance was over 50' - do we do as well today? Some of the branch meetings are interesting in retrospect:

- Professor W. H. Cockcroft on 'Mathematical teaching: our present situation' at Leeds

- Dr G. Matthews on 'Matrices for the million' at Exeter

- Mr E. H. Lockwood on 'Curves' at Cambridge

- Mr A. P. Rollett on 'Napoleon's theorem' at North Staffordshire.

All the branches appear to be extremely active and expanding in membership. Perhaps teachers had fewer alternative outlets for 'in service' type activity at that time.

The Gazette has changed considerably in recent years (the dull grey colour went a long time ago) as has the Mathematical Association itself. It remains a useful and absorbing pastime to browse through old Gazettes there is much to be found which is of current use, there is the amusement with things which now look hopelessly out of date and above all there is the feeling that the teaching of mathematics throws up issues which do not really alter much with time.

MICHAEL CORNELIUS, Chair of Council Folly Lodge, South Cadbury, Yeovil BA22 7ES

Mike Cornelius achieved his BA in 1961 from Cambridge University. After teaching in St Albans, Birkenhead and Yeovil he joined the University of Durham in 1970. He has written Teaching mathematics, Board games round the world, What's your game? and Test your number power and first wrote for the Gazette in 1972. He joined the Association in 1961 serving as Diploma Committee secretary and Editor-in-Chief before becoming Chair of Council in 1993. His interests include numeracy, gifted pupils and games in teaching mathematics. He enjoys golf, bridge and walking.

School for scandal

The rejected Octavia found solace in the arms of a woman, the intellectual firebrand and pioneering feminist Sophia Jex-Blake, who had shocked her middle-class parents by becoming a mathematics lecturer at Queens College, London, a scandalous act for a woman of means in the 1870s.

Sunday Telegraph 3 September 1995, sent in by Nick Lord. 